\title{
Gold grade variation and stream sediment geochemistry of the Vaimba-Lidi drainage system, northern Cameroon (West Africa)
}

\author{
Victor F. Embui ${ }^{1}$, Benjamin O. Omang ${ }^{1,2}$, Vivian B. Che ${ }^{3}$, Melvin T. Nforba ${ }^{4}$, \\ Emmanuel C. Suh ${ }^{1,3^{*}}$ \\ ${ }^{1}$ Economic Geology Unit, Department of Geology, University of Buea, Buea, Cameroon; \\ *Corresponding Author: chuhma@yahoo.com \\ ${ }^{2}$ Department of Mineral Resource Engineering Technology, Federal Polytechnic Auchi, Auchi, Nigeria \\ ${ }^{3}$ Remote Sensing Unit, Department of Geology, University of Buea, Buea, Cameroon \\ ${ }^{4}$ Department of Earth Sciences, University of Yaounde I, Yaounde, Cameroon
}

Received 16 January 2013; revised 14 February 2013; accepted 26 February 2013

\section{ABSTRACT}

Stream sediment geochemistry remains a versatile tool in exploration especially in regions where knowledge of the primary mineralization is lacking and the exploration activities are still at reconnaissance stage. In this study, we investigate the concentrations of gold and associated elements in stream sediment samples from the Vaimba-Lidi drainage system in northern Cameroon; a relatively remote area where alluvial gold is worked locally, and exploration activities are at early stage. The main river and its principal first and second order tributaries were sampled, panned for gold grain recovery and the $\mathbf{1 0 0} \mu \mathrm{m}$ size fraction analyzed for Au by fire assay with $\mathrm{Ni}$ finish. A suite of other elements were analyzed for by inductively coupled plasma mass spectrometry (ICP-MS). Gold grades estimated by the panning and weighing technique rarely exceed $1 \mathrm{~g} / \mathrm{t}$ while the Au concentrations from chemical analysis range from 3.0 to $354.0 \mathrm{ppm}$. The spatial distribution of gold and all the other elements are presented as point symbol maps and the data analyzed using multivariate statistics. From the principal component analysis (PCA), the As-Mo-W-Ag as well as the Au-Zn factors point to the presence of primary hydrothermal gold-sulphide mineralization in the area and this can be further investigated. These results highlight the importance of multielement analysis and multivariate statistical interpretation of sediment geochemical data in inferring the nature of the underlying primary mineralization in any region.
Keywords: Gold Grade; Principal Component Analysis (PCA); Geochemistry; Stream Sediments; Cameroon

\section{INTRODUCTION}

Gold exploration using stream sediments commonly relies on two combined approaches: the proportion of gold grains in the heavy mineral fraction and the bulk major and/or trace element content of the samples. For the heavy mineral fraction, samples are often weighed on the field, sieved and the recovered gold grains weighed. This approach gives a first pass indication of the gold potential within the catchments area and assists in delineating areas for further investigation. A significant aspect of research is to find out if areas of high gold grades determined by the panning and weighing method correlate positively with areas of high gold concentrations determined by bulk sample geochemistry. Also, the spatial display of stream sediment geochemical data as well as the statistical treatment of the data can unravel element associations that are relevant to primary exploration in the region. These associations are also useful in speculating on the source region lithology, geological processes and the nature of the primary (rock-hosted) mineralization, if any is present [e.g., 1-3].

In exploring for gold using stream sediments, it is often more effective to analyse for the spatial distribution of a suite of elements than simply looking at gold alone. Gold usually occurs in association with other elements such as $\mathrm{Cu}, \mathrm{As}, \mathrm{Zn}, \mathrm{Fe}, \mathrm{Pb}, \mathrm{W}$ (when the gold is associated with chalcopyrite, arsenopyrite, sphalerite, pyrite, galena and scheelite, respectively, in hydrothermal veins) $[4,5]$. Therefore, to obtain any meaningful interpretation of geochemical data from stream sediments, the data must be handled with the appropriate techniques which 
will permit the differentiation of the various processes that lead to their formation and modification in the primary and secondary environments. This is often achieved by using various multivariate statistical methods such as factor and cluster analysis together with two-dimensional single element point symbol maps [e.g., 5-9] for elemental spatial distribution display.

In Cameroon, alluvial gold exploitation commenced in the early 1940s and continues to date although records declaring the output of this activity during this period are unavailable. Most of the small-scale alluvial gold mining operations are located in the Lom Basin of the Betare Oya district (Figure 1) and to the south of it extending to the Batouri district [4]. The region extending northwards from the Betare Oya district has witnessed little or no exploration works. With the fear that rising waters of the Lagdo dam (Figure 2(a)) might flood the entire region, a

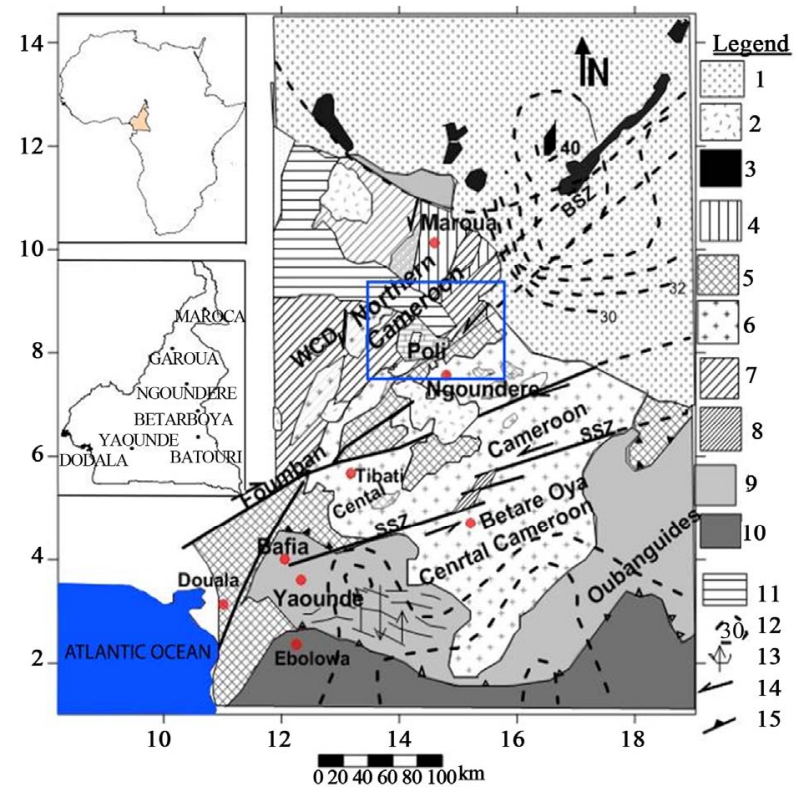

Figure 1. Lithostructural map of Cameroon (modified from [24]) showing the major structural domains in Cameroon. Note the dominance of NE-SW-trending structures along which the Betare_Oya (Lom Basin) gold district is situated. Blue box shows location of the Viamba-Lidi drainage system within the Poli group, northern Cameroon. 1: Quaternary sediments; 2: Neogene volcanics; 3: Massenya-Ounianga gravity highs (10 $30 \mathrm{mGal}$ ); 4: Poli group (active margin Neopoterozoic supracrustal and juvenile intrusions); 5: Adamawa-Yaounde and Nyong Paleoproterozoic remnants; 6: Late syntectonic subalkaline granitoids; 7: Western Cameroon Domain (WCD: early syntectonic basic to intermediate calc-alkaline intrusions. 660 $600 \mathrm{Ma}$ ); 8: Lom syntectonic basin (meta-sediments, conglomerates, volcanic ashes and lavas); 9: Yaounde Group (intracratonic deposits); 10: Craton and inferred craton; 11: Mesozoic sediments (Benue Trough); 12: Effective elastic thickness curves $(\mathrm{km})$; 13: Foliation and lineation trends; 14: Left lateral sense of wrench movement; 15: Main thrust zone likely associated to crust redoubling zone. WCD: West Cameroon Domain. new and aggressive approach to exploration in this little known (in economic geology terms) northern part of Cameroon with regards to $\mathrm{Au}$ mineralization is witnessing a heightened level of attention from both private investment groups and public research institutions like the Universities. This contribution falls within this context and examines part of the drainage system that empties into the Lagdo dam.

Previous published works on gold mineralization in $\mathrm{Ca}-$ meroon have examined the style of hydrothermal vein mineralization [4], the morphology and microchemistry of gold grains [11], the alteration and gold grade variation in wall rock in the Lom series [12] as well as geophysical delineation of favourable host structures [13]. Stream sediments have by and large received little attention. In an attempt to open new gold potentials in the northern part of the country, we designed a stream sediment survey targeting the Vaimba-Lidi drainage system in the north of Cameroon (Figure 2(b)) that flows into the Lagdo dam. Here we show that areas of high gold grade determined by the weighing and panning method are differrent from those determined by bulk sample geochemistry, suggesting that gold might have different source lithologies in the area and occur in different forms. This may also reflect the presence of gold nuggets in the $>100 \mu \mathrm{m}$ size fraction. Also we show using multivariate statistics that gold is its own best pathfinder element although the As-Mo-W association suggests the presence of sulphide-dominated hydrothermal mineralization in the catchment area. The other trace element associations show that granitic rocks underlie most of the catchment and we speculate that a primary granite-related gold mineral system is the princepal controlling factor. These results are of more than local significance and add to the global discourse on the use of stream sediments for gold exploration in humid tropical settings.

\section{LOCATION OF STUDY AREA AND REGIONAL GEOLOGICAL FRAMEWORK}

The Vaimba-Lidi drainage system is part of the wider Benue basin river system in the north of Cameroon (Figure 2). The Benue basin river system has a NE-SW orientation and extends from southern Chad across northern Cameroon into northern Nigeria and represents one of the major drainage systems in West Africa. Farther downstream in Nigeria, the Benue merges with river Niger that empties into the Atlantic Ocean farther south. The area of study lies between longitudes $14^{\circ} 10^{\prime} \mathrm{E}$ and $14^{\circ} 50^{\prime} \mathrm{E}$ and latitudes $8^{\circ} 30^{\prime} \mathrm{N}$ and $8^{\circ} 60^{\prime} \mathrm{N}$ with spot heights that do not exceed $200 \mathrm{~m}$ above sea level.

The Vaimba-Lidi river system (Figure 2) drains an area dominated by volcano-sedimentary rocks that constitute part of the Pan-African mobile belt sandwiched between the Congo Craton to the south (Figure 1) and the West African Craton to the west. Excellent reviews 


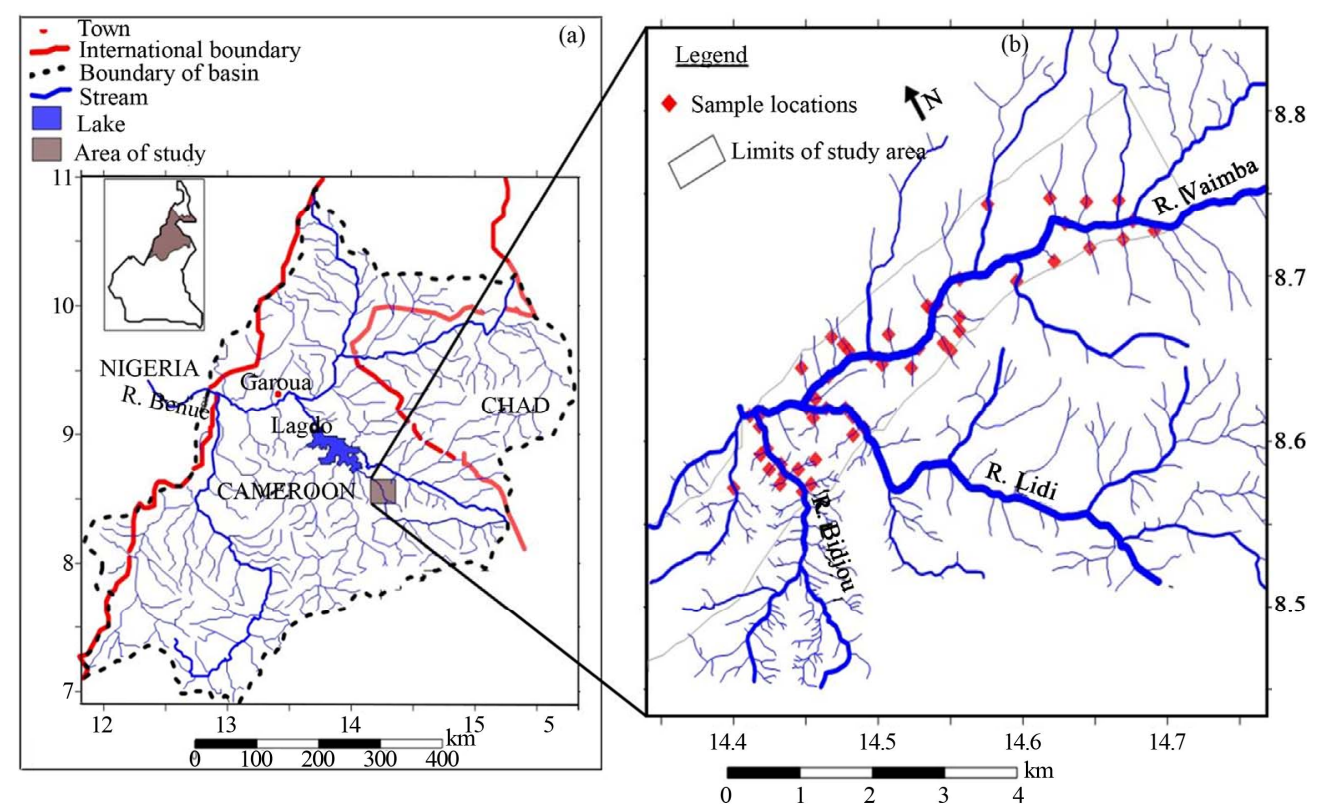

Figure 2. (a) The Benue basin modified after [10] trending NE-SW from Chad across Cameroon into Nigeria. Various streams or tributaries flowing within this basin drain into the Benue River, a major river feeding the Niger River in Nigeria. The area of study within this basin is the Vaimba-Lidi drainage system in the NE gold field of Cameroon. (b) Sample location map within the Vaimba-Lidi drainage system. In all 51 samples were collected from active stream sediments.

on this regional picture are provided in [14-18]. Petrologic and isotopic studies have shown that this Pan-African geotectonic unit in Cameroon can be subdivided into three groups, namely the Yaoundé Group (southern Cameroon), the Adamawa domain (central Cameroon) and the Poli Group (northern Cameroon). The study area is part of the Poli group with volcano-sedimentary lithologies reminiscent of an early Neoproterozoic back-arc basin formed between 830 and 665 Ma [19,20]. These sediments were then subjected to deformation, metamorphism, and intensive plutonism between 630 and 580 Ma [19,21-24]. Stratigraphically, the rock units have a very poor resolution since they are interleaved and strongly deformed $[22,23]$ although it is widely believed that there is an alternation between metavolcanic and metasedimentary rocks. In this area volcanogenic clastic rocks (mainly tuffs) and reworked clastic rocks (metagreywackes) with conglomerate layers are common [25]. Rhyolite and tholeiitic basalts are the rock types that make up the metavolcanic unit. Granitic intrusions, mainly of Pan-African age, are widespread in the area and their emplacement was controlled by the development of late strike slip faults that crosscut early gently folded structures with E-W-trending axial surfaces. These plutons are calc-alkaline to alkaline in compositions [19].

\section{MATERIALS AND METHODS}

Fifty one (51) active stream sediment samples were collected at various points within the drainage basin (as shown in Figure 2(b)) defining an area $\sim 10.4 \mathrm{~km}^{2}$. First and second order tributaries as well as the main Lidi and Vaimba rivers were sampled. Samples from second order tributaries were collected at suitable sites above their confluence point. In the field, homogenized samples were in situ sub divided into two fractions and weighed. In order to obtain $\mathrm{Au}$ grade by the panning and weighing method, one fraction from each sampling point was first weighed, then panned and later in the camp gold grains in the dried heavy mineral concentrate were handpicked under a binocular microscope and weighed. This gave an indication of the gold grade in each sample and the grade variation thus determined is presented in Figure 3. The remaining fraction was wet sieved in the field and the $100 \mu \mathrm{m}$ size fraction retained for further laboratory geochemical analysis.

In the laboratory, each $100 \mu \mathrm{m}$ size fraction was sub divided into two subsets. Trace element concentrations were determined from one subset by ICP-MS and Au from the other by fire assay with a nickel finish. These subsets were first crushed and milled to fine powder. With the ICP-MS method, an argon plasma which reaches working temperatures of $6000^{\circ} \mathrm{C}-8000^{\circ} \mathrm{C}$ was generated by radio frequency excitation. Solutions prepared from $10 \mathrm{~g}$ of each of the samples was fused with lithium-borate, metaborate and then leached with $30 \%$ dilute nitric acid $\left(\mathrm{HNO}_{3}\right)$ were injected into the plasma. This solution was excited and produced analyte ions 


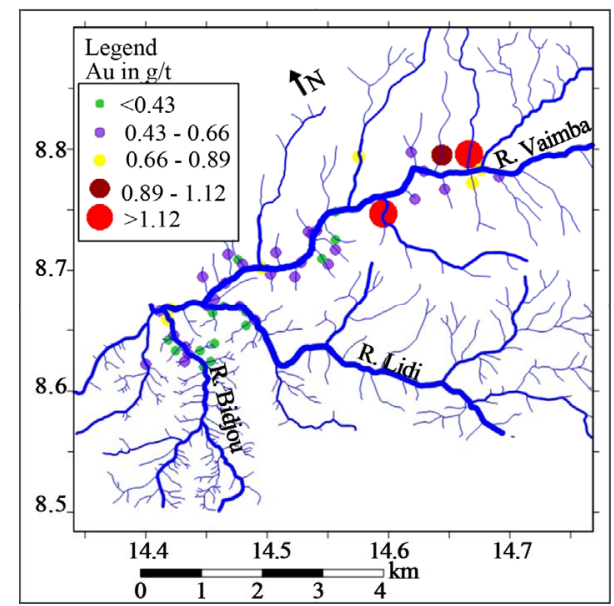

Figure 3. Graduated symbol plot for visible $\mathrm{Au}$ by panning and weighing technique $(\mathrm{g} / \mathrm{t})$ overlain on the drainage map of the Vaimba-Lidi area of north Cameroon. Large red bubbles indicate locations with elevated $\mathrm{Au}$ content.

which were separated and measured by mass spectrometry (MS). To measure Au concentration by the fire assay method $10 \mathrm{~g}$ of an aliquot powdered sample was mixed with soda ash (sodium carbonate). To this mixture, $\mathrm{Ni}$ collector was added in solution. The well mixed material was then fired at temperatures ranging from $1100^{\circ} \mathrm{C}$ to $1200^{\circ} \mathrm{C}$ in a crucible. As the $\mathrm{Ni}$ in the melt settled to the bottom of the crucible, it scavenged the Au from the melt. This nickel was then collected and dissolved out leaving a tiny $\mathrm{Au}$ flake which was weighed (gravimetric technique).

\section{RESULTS}

\subsection{Gold Grade Estimated by the Panning and Weighing Technique}

The gold grades estimated by weighing picked gold grains are generally low and erratic and only a few values exceed $1 \mathrm{~g} / \mathrm{t}$ (Figure 3 ).

The point symbol map or spatial plot (Figure 3) shows this variation with the relatively higher Au concentrations found in the head water areas of river Vaimba which flows from east to west (Figure 3). The grade decreases downstream along this river (Figure 3) away from the catchment area. All gold grades for samples collected along the Lidi River and its principal tributaries as well as the Bidjou River were below $1 \mathrm{~g} / \mathrm{t}$ (Figure 3).

\subsection{Geochemical Analysis}

As stated before, a total of 51 samples were analysed for a whole suite of elements and only the 19 elements with concentrations above the detection limit are reported here. The raw data set can be obtained upon request from the corresponding author. These geochemical data are summarized in Table 1. To investigate the inter element relationship, the raw data were log transformed and a Pearson's correlation matrix was computed for the elements (Table 2). From Table $2 \mathrm{Au}$ has a relatively high correlation value of 0.43 only with $\mathrm{Zn}$. Other element pairs with high positive $\mathrm{r}$ values include $\mathrm{Y}-\mathrm{Nb}$, $\mathrm{Cu}-\mathrm{Y}, \mathrm{Cu}-\mathrm{Nb}$, La-Ce. A few elements such as $\mathrm{Cu}-\mathrm{Ba}$ and $\mathrm{Cu}-\mathrm{Sr}$ have very low correlation coefficients. To further investigate these element associations, the data were subjected to principal component factor analysis [26].

Five factors or components were generated (Table 3) with each representing a cluster of interrelated elements within the data set. These five factors are as follows:

Factor 1: Y-Nb-Cu-Zr

Factor 2: Sr-Sb-Ba-La-Ce-Pb

Factor 3: As-Mo-W-Ag

Factor 4: Cd

Factor 5: Au-Zn.

The association of $\mathrm{Au}$ and $\mathrm{Zn}$ define a factor on its own pointing to possible sphalerite mineralization associated with gold in the underlying rock. Factor 3 is a

Table 1. Basic statistics of stream sediments geochemical data generated by ICP-MS and fire assay technique for 51 stream sediment samples obtained from the Vaimba-Lidi drainage system in the Benue basin northern Cameroon.

\begin{tabular}{|c|c|c|c|c|c|c|c|c|}
\hline Elements & No & Range & Min & Max & Mode & Median & Mean & Std. D \\
\hline $\mathrm{Au}$ & 26 & 351.00 & 3.00 & 354.00 & 10.00 & 17.00 & 45.514 & 84.16 \\
\hline $\mathrm{Cu}$ & 51 & 78.00 & 10.00 & 88.00 & 37.00 & 36.00 & 31.75 & 14.45 \\
\hline $\mathrm{Zn}$ & 51 & 63.00 & 36.00 & 99.00 & 62.00 & 59.00 & 59.80 & 14.11 \\
\hline As & 51 & 81.00 & 5.00 & 86.00 & 18.00 & 21.00 & 26.35 & 18.10 \\
\hline $\mathrm{Sr}$ & 51 & 148.00 & 30.00 & 178.00 & 42.00 & 48.00 & 56.63 & 24.74 \\
\hline Y & 51 & 42.00 & 21.00 & 63.00 & 42.00 & 38.00 & 37.47 & 7.95 \\
\hline $\mathrm{Nb}$ & 51 & 71.00 & 37.00 & 108.00 & 61.00 & 63.00 & 64.53 & 11.66 \\
\hline Mo & 51 & 3.00 & 1.00 & 4.00 & 1.00 & 2.00 & 1.61 & 0.70 \\
\hline $\mathrm{Ag}$ & 51 & 0.10 & 0.10 & 0.20 & 0.100 & 0.100 & 0.10 & 0.01 \\
\hline $\mathrm{Cd}$ & 51 & 1.00 & 1.00 & 2.00 & 1.00 & 1.00 & 1.02 & 0.14 \\
\hline Sn & 51 & 0.00 & 5.00 & 5.00 & 5.00 & 5.00 & 5.00 & 0.00 \\
\hline $\mathrm{Sb}$ & 51 & 13.00 & 5.00 & 18.00 & 5.00 & 6.00 & 7.80 & 3.64 \\
\hline $\mathrm{Ba}$ & 51 & 855.00 & 240.00 & 1095.00 & I & 587.00 & 594.41 & 174.11 \\
\hline $\mathrm{La}$ & 51 & 42.00 & 10.00 & 52.00 & 10.00 & 19.00 & 21.76 & 10.60 \\
\hline $\mathrm{Ce}$ & 51 & 107.00 & 56.00 & 163.00 & 81.00 & 90.00 & 93.06 & 24.89 \\
\hline $\mathrm{W}$ & 51 & 14.00 & 1.00 & 15.00 & 1.00 & 1.00 & 2.27 & 2.28 \\
\hline $\mathrm{Pb}$ & 51 & 37.00 & 7.00 & 44.00 & 22.00 & 24.00 & 24.67 & 7.72 \\
\hline $\mathrm{Bi}$ & 51 & 0.00 & 1.00 & 1.00 & 1.00 & 1.00 & 1.00 & 0.00 \\
\hline $\mathrm{Zr}$ & 51 & 547.00 & 365.00 & 912.00 & 520.00 & 586.00 & 602.51 & 126.31 \\
\hline
\end{tabular}

No represents the number of samples with concentrations above their detection limit used to calculated the statistics, Min, Max, Std. D represents the Minimum, Maximum concentration value and standard diversion, respectively, / represents no value. 
Table 2. Pearson's linear correlation coefficient matrix derived from stream sediment samples from the Vaimba-Lidi drainage system, North Cameroon.

\begin{tabular}{|c|c|c|c|c|c|c|c|c|c|c|c|c|c|c|c|c|c|}
\hline & $\mathrm{Au}$ & $\mathrm{Cu}$ & $\mathrm{Zn}$ & As & $\mathrm{Sr}$ & $\mathrm{Y}$ & $\mathrm{Nb}$ & Mo & $\mathrm{Ag}$ & $\mathrm{Cd}$ & $\mathrm{Sb}$ & $\mathrm{Ba}$ & $\mathrm{La}$ & $\mathrm{Ce}$ & W & $\mathrm{Pb}$ & $\mathrm{Zr}$ \\
\hline $\mathrm{Au}$ & 1 & & & & & & & & & & & & & & & & \\
\hline $\mathrm{Cu}$ & 0.07 & 1 & & & & & & & & & & & & & & & \\
\hline $\mathrm{Zn}$ & 0.43 & 0.43 & 1 & & & & & & & & & & & & & & \\
\hline As & -0.02 & 0.18 & -0.12 & 1 & & & & & & & & & & & & & \\
\hline $\mathrm{Sr}$ & -0.01 & -0.53 & 0.04 & -0.25 & 1 & & & & & & & & & & & & \\
\hline $\mathrm{Y}$ & 0.06 & 0.82 & 0.45 & 0.09 & -0.20 & 1 & & & & & & & & & & & \\
\hline $\mathrm{Nb}$ & 0.10 & 0.77 & 0.49 & 0.17 & -0.17 & 0.85 & 1 & & & & & & & & & & \\
\hline Mo & -0.01 & 0.29 & -0.15 & 0.49 & -0.29 & 0.12 & 0.18 & 1 & & & & & & & & & \\
\hline $\mathrm{Ag}$ & -0.01 & 0.08 & 0.05 & 0.25 & -0.08 & 0.08 & 0.02 & 0.08 & 1 & & & & & & & & \\
\hline $\mathrm{Cd}$ & -0.05 & -0.21 & 0.02 & -0.07 & 0.07 & -0.30 & -0.14 & 0.08 & -0.02 & 1 & & & & & & & \\
\hline $\mathrm{Sb}$ & -0.12 & -0.24 & -0.15 & 0.25 & 0.31 & -0.16 & -0.14 & 0.25 & 0.32 & 0.20 & 1 & & & & & & \\
\hline $\mathrm{Ba}$ & -0.05 & -0.58 & -0.16 & 0.02 & 0.51 & -0.40 & -0.16 & -0.19 & -0.10 & 0.16 & 0.27 & 1 & & & & & \\
\hline $\mathrm{La}$ & -0.02 & 0.02 & 0.10 & 0.04 & 0.31 & 0.20 & 0.37 & 0.18 & -0.10 & 0.08 & 0.26 & 0.37 & 1 & & & & \\
\hline $\mathrm{Ce}$ & -0.08 & 0.07 & 0.01 & 0.04 & 0.29 & 0.23 & 0.43 & 0.13 & 0.04 & 0.09 & 0.27 & 0.35 & 0.89 & 1 & & & \\
\hline W & -0.15 & -0.05 & -0.09 & 0.47 & -0.01 & -0.04 & -0.04 & 0.21 & 0.17 & 0.05 & 0.39 & 0.10 & 0.15 & 0.07 & 1 & & \\
\hline $\mathrm{Pb}$ & -0.03 & -0.09 & 0.10 & 0.09 & 0.11 & -0.10 & 0.08 & 0.37 & -0.23 & 0.10 & 0.22 & 0.36 & 0.62 & 0.38 & 0.13 & 1 & \\
\hline $\mathrm{Zr}$ & -0.06 & 0.19 & 0.07 & 0.04 & 0.19 & 0.53 & 0.43 & 0.19 & 0.26 & -0.27 & 0.16 & -0.01 & 0.46 & 0.56 & 0.01 & 0.13 & 1 \\
\hline
\end{tabular}

Table 3. Principal component factor matrix (five factor model) for stream sediments geochemical data from the Vaimba-Lidi drainage system, northern Cameroon.

\begin{tabular}{|c|c|c|c|c|c|}
\hline \multirow{2}{*}{ Variables } & \multicolumn{5}{|c|}{ Component } \\
\hline & 1 & 2 & 3 & 4 & 5 \\
\hline $\mathrm{Au}$ & 0.134 & -0.162 & -0.250 & 0.205 & 0.653 \\
\hline $\mathrm{Cu}$ & 0.863 & -0.364 & 0.098 & 0.117 & -0.029 \\
\hline $\mathrm{Zn}$ & 0.484 & -0.147 & -0.396 & 0.141 & 0.622 \\
\hline As & 0.236 & 0.151 & 0.739 & 0.068 & 0.127 \\
\hline $\mathrm{Sr}$ & -.304 & 0.543 & -0.446 & -0.315 & 0.177 \\
\hline $\mathrm{Y}$ & 0.912 & -0.142 & -0.124 & -0.161 & -0.045 \\
\hline $\mathrm{Nb}$ & 0.901 & 0.051 & -0.153 & 0.052 & 0.026 \\
\hline Mo & 0.341 & 0.209 & 0.618 & 0.377 & -0.092 \\
\hline $\mathrm{Ag}$ & 0.145 & 0.019 & 0.402 & -0.618 & 0.370 \\
\hline $\mathrm{Cd}$ & -0.269 & 0.214 & 0.049 & 0.344 & 0.308 \\
\hline $\mathrm{Sb}$ & -0.112 & 0.591 & 0.405 & -0.237 & 0.295 \\
\hline $\mathrm{Ba}$ & -0.384 & 0.667 & -0.208 & 0.016 & 0.082 \\
\hline $\mathrm{La}$ & 0.372 & 0.821 & -0.215 & 0.153 & -0.085 \\
\hline $\mathrm{Ce}$ & 0.411 & 0.770 & -0.204 & -0.069 & -0.136 \\
\hline W & 0.016 & 0.319 & 0.592 & -0.050 & 0.204 \\
\hline $\mathrm{Pb}$ & 0.107 & 0.629 & -0.009 & 0.561 & -0.051 \\
\hline $\mathrm{Zr}$ & 0.569 & 0.407 & -0.095 & -0.463 & -0.190 \\
\hline$\%$ of variance & 2.358 & 19.613 & 13.028 & 8.632 & 7.675 \\
\hline
\end{tabular}

typical primary mesothermal sulphide \pm gold mineralizetion paragenesis. The other factors, especially with the rare earth elements $\mathrm{La}$ and $\mathrm{Ce}$ point to the presence of granitic rocks possibly bearing $\mathrm{Pb}$ and $\mathrm{Cu}$ sulphide disseminations and thus reflect a lithologic control.

To enhance the data presentation and interpretation we generated point symbol maps for elements that make up the factors 3 and 5 using the software Surfer 9. The data for each element were then superimposed on a georeferenced drainage map of the study area. These plots show that $\mathrm{Au}$ and $\mathrm{Zn}$ have high values along the River Bidjou (Figures 4(a) and 4(b)). Indeed $\mathrm{Zn}$ has high values extending upstream along this river into areas where panning also yielded high gold grades (Figure 3). The factor 3 elements rather have high concentrations along the tributaries notably the Lidi River (Figures 5(a)-(c)).

\section{INTERPRETATION AND DISCUSSION}

In the Vaimba-Lidi drainage system, gold grades estimated by both panning and weighing technique and bulk sample ICP-MS geochemical analysis are highly variable. Also the samples with high gold grades estimated by weighing do not coincide with the samples having high gold grades analyzed by the ICP-MS method. In fact the samples with high values from both methods are spatially distinct. This can be explained by one or both phenomena that are examined below. 

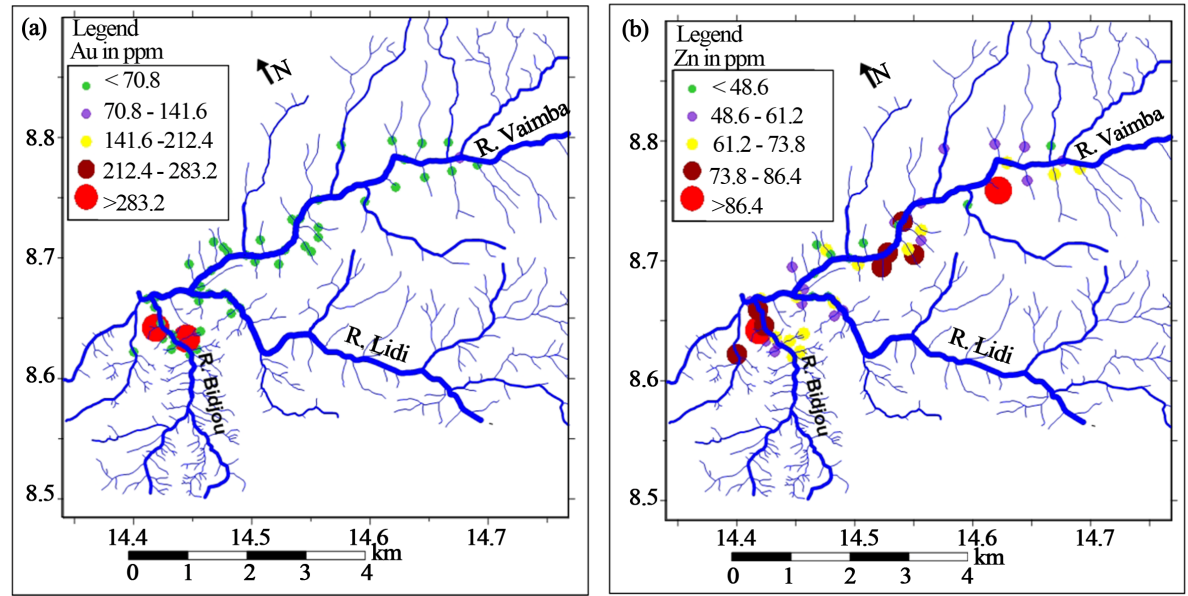

Figure 4. Graduated symbol plot for (a) Au and (b) Zn concentrations determined by fire assay and ICP-MS, respectively overlain on the drainage map of the Vaimba-Lidi area of north Cameroon. High positive scores (large bubbles) indicate locations with elevated $\mathrm{Au}$ and $\mathrm{Zn}$ content.
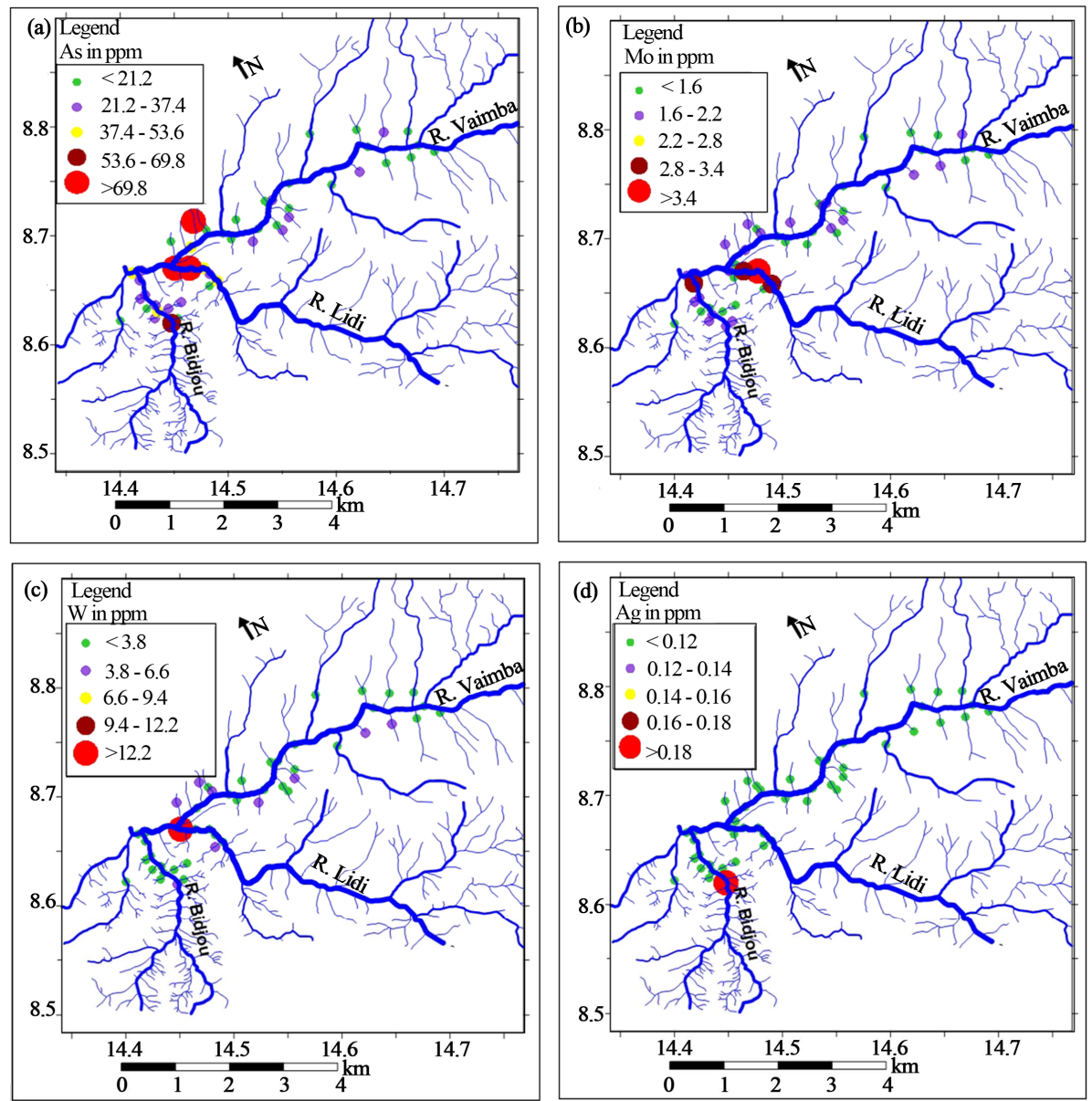

Figure 5. Graduated symbol plot for (a) As, (b) Mo, (c) W and (d) Ag scores (ppm) superimposed on the drainage map of the Vaimba-Lidi area of north Cameroon. High positive scores (large bubbles) indicate locations with anomalous concentrations.

The observation that samples from the river Vaimba sediments with high gold grades from the panning method do not also have high gold grades determined by geochemistry might indicate that gold in these sediments 
is coarse grained (nuggets). Therefore the $100 \mu \mathrm{m}$ size fraction we analyzed is not necessarily the most appropriate fraction for exploration along this river channel. The issue of sporadic and erratic gold grade values in various size fractions is a major challenge in stream sediment studies applied to gold exploration. For example, [27] demonstrated in the Sungai Kuli area of Malaysia that gold values are highest in the gravel size fraction and decrease with decreasing grain size down to the -53 $\mu \mathrm{m}$ fraction. Such nugget effect must be taken into consideration for further exploration works along the Vaimba River.

The spatial discrepancy in gold grades determined by the two methods in this study might also indicate that more than one form of primary gold mineralization may exist in the region. These include free gold in hydrothermal quartz veins (accounting for high grades by panning) and gold bound in sulphides notably sphalerite possibly related to a hydrothermally altered wallrock or gold-sulphide-quartz veining (accounting for the high gold values from the ICP-MS analysis). Hydrothermal alteration of the wallrock also resulted in the formation of scheelite, molydenite and arsenopyrite leading to the development of the As-Mo-W and Ag metal association. The fact that gold is not in this paragenesis might suggest that this paragenesis represents another sulphidation event that is barren with respect to $\mathrm{Au}$.

This element association must therefore be handled with caution in lithogeochemical exploration in the region. Rather, the sphalerite-related sulphidation event holds a greater promise to finding primary gold mineralization in the region. Gold deposits in which sphalerite is related to the ore are well known [e.g., 5,28,29]. The argument in support of possible quartz vein mineralization in the area is examined further below. Hydrothermal alteration and mineralization in rocks that generate significant amounts of gold can often be detected through statistical and spatial analysis of geochemical data [5]. Weathering and erosion of rocks can generate sediments rich in elements derived from minerals related to gold mineralization and this has been demonstrated to be the case in this study area.

The other element associations that constitute factors 1 and 2 (Table 3) including Y-Nb-Cu-Zr-Sr-Sb-Ba-La-Ce$\mathrm{Pb}$ are interpreted to reflect a lithological control. These factors are not deemed to be related to the Au mineralization and are attributed to the weathering of granitic rocks and their subvolcanic equivalents, both with disseminated sulphides such as chalcopyrite $\left(\mathrm{CuFeS}_{2}\right)$ and galena $(\mathrm{PbS})$. The occurrence of high field strength elements in these associations is also ascribed to contributions from minerals such as monazite, celestite, stibnite, and zircon which are abundant in granitic rocks.

To have full insight into the meaning of the results of this study it is important to recall that the catchment area and drainage system examined has mainly volcanosedimentary rocks into which late granitic plutons have been intruded.

From an exploration point of view, the emplacement of these granitic bodies could have resulted in the generation of volatile emanations that remobilised $\mathrm{Au}$ and concentrated it together with sphalerite in the country rock as veins and altered wallrock halos. In such a model therefore, granitoid emplacement, sulphide deposition and gold mineralization are contemporaneous. These stream sediment data therefore suggest that the exploration strategy to be employed in the region must recognize the granitic batholiths as the principal lithology whose aureoles must be carefully mapped and sampled. Granite-related gold deposits also with a similar As-Mo-W paragenesis have been recognized in other parts of the world [e.g., 30,31] and references therein] and the results of this study suggest that such deposit type exists in northern Cameroon. In these other studies the granites are late and play a major role in the gold metallogenic system.

\section{CONCLUSIONS}

The main findings from this work can be summarized as follows.

- The gold grades estimated by panning and by ICP-MS have high values that are spatially unrelated. This suggests the influence of the nugget effect and that gold occurs in the area as free grains in quartz veins and as sulphide-related gold. The high gold grade tributaries in the region have now been earmarked for subsequent investigations.

- The element association defined by multivariate statistics between $\mathrm{Au}$ and $\mathrm{Zn}$ suggests that sphalerite deposition and gold mineralization are contemporaneous thus wallrocks with sphalerite are the most prospective during lithogeochemiacl surveys in the region.

- A barren sulphidation event marked by the formation of As-Mo-W-Ag paragenesis is also identified. Distinguishing these two sulphide formation events is crucial to successful exploration in the region.

- These results have highlighted the role granitic rocks play in the generation of mesothermal gold deposits. This adds to the wider international discourse on this theme and suggests that the mapping of granitic batholiths in this outcrop-poor region will enhance further primary gold exploration works.

\section{ACKNOWLEDGEMENTS}

This contribution is part of the economic geology research framework "The Precambrian Mineral Belt of Cameroon" at the University 
of Buea and forms part of the graduate research theses of EV and BOO. CES and CVB acknowledge financial support from the Faculty of Science, University of Buea towards the Remote Sensing Unit and through the University of Buea grant system. CES also acknowledges John Gray formerly of African Aura Resources Ltd. for initial assistance with access to the gold prospective areas of the north of Cameroon. BOO acknowledges the European Union Erasmus Mundus Mobility Scholarship program (STREAM) for financing his studies and research stay at the University of Buea.

\section{REFERENCES}

[1] Levinson, A.A. (1974) Introduction to exploration geochemistry. Applied Publishing Co., Calgary.

[2] Plant, J. and Hale, M. (1994) Drainage geochemistry. Handbook of exploration geochemistry. Elsevier, Amsterdam.

[3] Key, R.M., De Waele, B. and Liyungu, A.K. (2004) A multi- element baseline geochemical database from the western extension of the Central Africa Copperbelt in north- western Zambia. Transactions of the Institution of Mining and Metallurgy. Section B: Applied Earth Science, 113, B205-B226. doi:10.1179/037174504225005717

[4] Suh, C.E. Lehmann, B. and Mafany, G.T. (2006) Geology and geochemical aspects of lode gold mineralization at Dimako-Mboscorro, SE Cameroon. Geochemistry: Exploration, Environment, Analysis, 6, 295-309. doi:10.1144/1467-7873/06-110

[5] Ali, K., Cheng, Q., Wenchang, L. and Yongqing, C. (2006) Multi-element association analysis of stream sediment geochemistry data for predicting gold deposits in southcentral Yunnan Province, China. Geochemistry: Exploration, Environment, Analysis, 6, 341-348. doi:10.1144/1467-7873/06-109

[6] Xu, Y. and Cheng, Q. (2001) A fractral filtering technique for prospecting regional geochemical maps for mineral exploration. Geochemistry: Exploration, Environment, Analysis, 1, 147-156. doi:10.1144/geochem.1.2.147

[7] Grunsky, E.C. (2002) Statistical analysis in the geosciences. In: Atkinson, P.M., Ed. Encyclopaedia of Life Support Systems (EOLSS). EOLSS Publishers, Oxford.

[8] Harris, J.R., Wilkinson, L. and Grunsky, E.C. (2000) Effective use and interpretation of lithogeochemical data in regional mineral exploration programs; application of geographic information systems (GIS) technology. Ore Geology Reviews, 16, 107-143. doi:10.1016/S0169-1368(99)00027-X

[9] Salminen, R., Kashabano, J., Myumbilwa, Y., Petro, F.N. and Partanen, M. (2008) Indications of deposits of gold and platinum group elements from a regional geochemical stream sediment survey in NW Tanzania. Geochemistry: Exploration, Environment Analysis, 8, 313-322. doi:10.1144/1467-7873/08-179

[10] Olivry, J.C. (1986) Rivers and streams of Cameroon. Hydrological Monographs, 9, 745.

[11] Suh, C.E. and Lehmann, B. (2003) Morphology and electron-probe microanalysis of residual gold-grains at $\mathrm{Di}$ - mako, Southeast Cameroon. Annual Reviews in Mineralogy, 6, 255-275. doi:10.1127/0028-3649/2003/2003-0255

[12] Freyssinet, P.H., Lecompte, P. and Edimo, A. (1989) Dispersion of gold base metals in the Mborguene lateritic profile, east Cameroon. Journal of Geochemical Exploration, 32, 99-116. doi:10.1016/0375-6742(89)90050-2

[13] Fon, A.N., Che, V.B. and Suh, C.E. (2012) Application of electrical resistivity and chargeability data on a GIS platform in delineating auriferous structures in a deeply weathered lateritic terrain, eastern Cameroon. International Journal of Geosciences, 3, 960-971. doi:10.4236/ijg.2012.325097

[14] Fitches, W., Ajibade, A.C., Egbuniwe, I.G., Holt, R.W. and Wright, J.B. (1985) Late Proterozoic schist belt and plutonism in Northern Nigeria. Journal of the Geological Society of London, 142, 319-337. doi:10.1144/gsjgs.142.2.0319

[15] Nzenti, J.P., Barbey, P., Jegouzo, P. and Moreau, C. (1984) The Yaoundé Migmatite, an example of a new granulitic series within the Proterozoic collision belt in Cameroon. Annales of the Academy of Sciences, Paris, 299, 11971199.

[16] Pin, C. and Poidevin, J.L. (1987) U-Pb zircon evidence for a Pan-African granulite facies metamorphism in the Central African Republic. A new interpretation of the high-grade series of the northern border of the Congo Craton. Precambrian Research, 36, 303-312. doi:10.1016/0301-9268(87)90027-1

[17] Ngako, V. (1999) The Pan African continental deformation in Central Africa, a result of Himalayan type buckling. Ph.D. Thesis, University of Yaoundé I, Yaoundé.

[18] Ngako, V., Affaton, P. and Njonfang, E, (2008) Pan-African tectonics in northwestern Cameroon: Implication for the history of western Gondwana. Gondwana Research, 14, 509-522. doi:10.1016/j.gr.2008.02.002

[19] Toteu, S.F. (1990) Geochemical characterization of the main petrographical and structural units of northern Cameroon, implication for panafrican evolution. Journal of African Earth Sciences, 10, 615-624. doi:10.1016/0899-5362(90)90028-D

[20] Toteu, S.F., Penaye, J., Deloule, E., Van Schmus, W.R. and Tchameni, R. (2006) Diachronous evolution of volcano-sedimentary basins north of the Congo craton, insights from $\mathrm{U}-\mathrm{Pb}$ ion microprobe dating of zircons from the Poli, Lom and Yaounde' Groups (Cameroon). Journal of African Earth Sciences, 44, 428-442. doi:10.1016/j.jafrearsci.2005.11.011

[21] Fur, Y.L. (1971) $\mathrm{Cu}$ indices within volcano sedimentary rocks of the Poli series (Cameroon). Bulletin of the Geological Survey of France, 6, 79-91.

[22] Njel, U.O. (1986) The Paleogeography of a segment of the Pan-African orogenic volcano-sedimentary belt of the Poli Series North Cameroon. Annales of the Academy of Sciences, Paris, 30, 1737-1742.

[23] Pinna, P., Calvez, J.Y., Abessolo, A., Angel, J.M., Mekoulou-Mekoulou, T., Mananga, G. and Vernhet, Y. (1994) Neoproterozoic events in the Tcholliré area, Pan African crustal growth and geodynamics in central-northern Cameroon (Adamawa and North Provinces). Journal of 
African Earth Sciences, 18, 347-353. doi:10.1016/0899-5362(94)90074-4

[24] Toteu, S.F., Van Schmus, W.R., Penaye, J. and Michard, A. (2001) New U-Pb and Sm-Nd Data from north-central Cameroon and its bearing on the pre-Pan African history of central Africa. Precambrian Research, 108, 45-73. doi:10.1016/S0301-9268(00)00149-2

[25] Kouske, A.P., Suh, C.E., Ghogomu, R.T. and Ngako, V. (2012) Na-Metasomatism and uranium mineralization during a two-stage albitization at Kitongo, Northern Cameroon: structural and geochemical evidence. International Journal of Geosciences, 3, 258-279. doi:10.4236/ijg.2012.31028

[26] Grunsky, E.C. (2010) The interpretation of geochemical survey data. Geochemistry: Exploration, Environment, Analaysis, 10, 27-74.

[27] Fletcher, W.K. and Muda, J. (2003) Dispersion of gold in stream sediments of the Sungai Kuli region, Sabah, Malaysia. Geochemistry: Exploration, Environment, Analysis, 3, 51-56. doi:10.1144/1467-787302-044

[28] Harraz, H.Z., Hamdy, M.M. and El-Mamoney, M.H.
(2012) Multi-element association analysis of stream sediment geochemistry data for predicting gold deposits in Barramiya gold mine, Eastern Desert, Egypt. Journal of African Earth Sciences, 68, 1-14. doi:10.1016/j.jafrearsci.2012.03.009

[29] Ajayi, T.R and Suh, C.E. (1999) Partially extractable metals in the amphiboles of Ife-Ilesha area: A lithogeochemical approach for gold exploration. Journal of Mining and Geology, 36, 103-116.

[30] Jaguin, J., Poujol, M., Boulvais, P., Robb, L.J. and Paquette, J.L. (2012) Metallogeny of precious and base metal mineralization in the Murchison Greenstone Belt, South Africa: Indications from $\mathrm{U}-\mathrm{Pb}$ and $\mathrm{Pb}-\mathrm{Pb}$ geochronology. Mineralium Deposita, 47, 739-748. doi:10.1007/s00126-012-0422-7

[31] Zeng, Q., McCuaig, T.C., Hart, C.J.R., Jourdan, F., Muhling, J. and Bagos, L. (2012) Structural and geochronological studies on the Liba goldfield of the West Qinling orogen, central China. Mineralium Deposita, 47, 799-820. doi:10.1007/s00126-011-0398-8 